\title{
The Early Twentieth Century Avant-Garde AND THE NORDIC COUNTRIES. AN INTRODUCTORY TOUR D'HORIZON
}

\author{
Hubert van den Berg
}

The Nordic countries have played only a marginal role in existing historiographic studies of the classical avant-garde. General accounts of the aesthetic avant-garde in the first decades of the twentieth century focus, as a rule, on the manifestations of this avant-garde in the main Western-European cultural capitals of the period (cf. Piotrowski 2009). While metropolises like Paris and Berlin were undoubtedly pivotal to the development of the avant-garde as a whole (cf. Bradbury/McFarlane 1978, Casanova 2004, Hultén 1978), there can be no doubt that the avant-garde was not confined to these cities. The main centres of avant-garde activity were not isolated bulwarks, but rather market places where the transnational avant-garde met stemming from and giving new impulses to a plethora of smaller and larger pockets of resistance, which constituted an interrelated network of avant-gardists throughout Europe (with links to other continents as well). This wider presence is receiving increased attention, marking a shift in general surveys of the avant-garde (cf. van den Berg/Fähnders 2009). However, a comprehensive account of the presence of the avant-garde in Northern Europe is still missing. An admirable, but all too brief, inventory of the avant-garde in the Nordic countries appeared as an exhibition catalogue some fifteen years ago (cf. Moberg 1995), and since then monographic studies and exhibition catalogues devoted to single Nordic artists or movements (cf. Ahlstrand 2000, Askeland 1987) and locations, in particular in Denmark (cf. Aagesen 2002, Alin/Kjerström Sjölin 1997, Jelsbak 2006) 
have appeared. Yet the wider panorama of the avant-garde in the Nordic countries remains a desideratum. Whereas this collection of essays does not aim to present a comprehensive history of the classical avant-garde in the Nordic countries, it does aim to fill the lacuna referred to above on two fronts, by approaching both avant-garde manifestations in the Nordic countries and the participation of artists from the Nordic countries in avant-garde ventures abroad. ${ }^{0}$

\section{Nordic Artists in the European Avant-Garde}

This collection documents the presence of Nordic artists in Paris and Berlin from the fauvist origins of the avant-garde to constructivism in the early twenties. Although several dozen artists from the Nordic countries can be found in these European avant-garde centres in the first decades of the twentieth century, there can be no doubt that the majority played only minor roles in the transnational arena. Their written work did not have the international circulation of the poems and manifestos of Guillaume Apollinaire, Filippo Tommaso Marinetti, Theo van Doesburg/I.K. Bonset, Kasimir Edschmid, Ivan Goll, Kurt Schwitters or Tristan Tzara. In the field of the visual arts, Nordic artists could be found in private academies of internationally renowned avant-garde painters, like the Parisian Académie Matisse (cf. Cohen 2001) and Académie Moderne of Othon Friesz, Ferdinand Léger, André Lhote and Amadée Ozenfant (cf. Derouet 1992), the classes of Aleksandr Archipenko in Berlin (cf. Terman Frederiksen 1987-88 I), the Dresden Kunstschule Der Weg (cf. Kesting 1925) or the Bauhaus in Weimar (cf. Askeland 1987). Some of them became important players in their respective national cultural fields, like the Swedes Sigrid Hjertén and Isaac Grünewald, the Norwegians Jean Heiberg and Henrik Sørensen (cf. Ahlstrand 2000, Werenskiold 1972) or the Finn Tyko Sallinen (cf. Ilmonen 1999, Levanto 1987). Others received little contemporary recognition in their home countries, like the Dane Franciska Clausen and the Norwegians Ragnhild Kaarbø, Ragnhild Keyser, and Charlotte Wankel, who were all doubly handicapped as female avant-garde painters (cf. Kielgast 2006). Another case is the Icelandic Finnur Jónsson, who dropped the constructivist style he had developed in Dresden when he returned to Iceland, since his abstract work found little appreciation in the mid-twenties; recognition followed only after World War II (cf. van den Berg 2006b). 
A handful of artists with a background in the Nordic countries were players on the transnational art scene - rather than Nordic artists working for a certain period in an international context spending most, if not all, of their active artistic life outside Scandinavia. Rolf de Maré, Jean Börlin and their Ballets Suédois were involved in theatrical and cinematic experiments in the context of Dada and surrealism in Paris, notably in the staging of Francis Picabia's ballet Relâche, scored by Erik Satie and boasting a film Entr'acte directed by René Clair (cf. Mas 2008, Sanouillet 1993). Nell Walden, born Roslund in Landskrona, was the second wife of the editor of the Berlin avant-garde journal Der Sturm and the owner of the eponymous art gallery, Herwarth Walden. Although Herwarth Walden was the nominal head of both the journal and gallery, Nell Walden was no less pivotal to the enterprise as an eminence grise, not least in supplying economic support for Der Sturm from 1912 to 1924 (cf. Ahlstrand 2000, Alms/Steinmetz 2000, van den Berg 2005b, 2009, Mark 1999).

Despite his very Scandinavian first (or actually, second) name and his Swedish passport, Helmuth Viking Eggeling, son of a German immigrant, had virtually no relationship with Sweden. Apart from his youth which he spent in Lund - he left Sweden at the age of seventeen in 1897 - Eggeling belonged to the international cultural arena in Germany, France and (for a short time during World War I) Switzerland, and was not only involved in Dada in Zurich but also one of the protagonists of constructivism, laying the foundations for abstract experimental avant-garde film (cf. O'Konor 1971, 2006). Eggeling is now regarded in Sweden as a major Swedish avant-garde figure; however, it took many decades before he entered Swedish art history at all. In the first half of the twentieth century he was probably regarded as being no more Swedish than Ivan Puni might be regarded as being Finnish. Puni was born in the - now Russian - town of Kuokkala/Repino on the Karelian Isthmus in 1892, when the summer resort was still within the borders of the Grand-Duchy of Finland, yet was of Russian descent and as such not seen as an avant-garde artist with a Finnish background (cf. Berninger/Cartier 1992).

The cases of Eggeling and Puni are demonstrative of the complex cultural geography related to the activities of the avant-garde in the early twentieth century. Similar examples can be found in the case 
of two key figures of the early European avant-garde, Emil Nolde and Emmy Hennings, who came from the Danish-German border country of Schleswig and were part-Danish, both in terms of their ancestry and acculturation (cf. Bak/Ørskou 2009, Echte 1999 and Reetz 2001). Schleswig had been under Danish rule for centuries and also had a strong Danish element, but became Prussian in 1864. In 1920, the Northern part of Schleswig - North of Sønderå and Flensburg - was returned to Denmark. Nolde's self-chosen family name (he was born in 1867 as Emil Hansen) points to his birthplace: the small hamlet Nolde, now just north of the Danish-German border, marked by the stream Sønderå. Part of his early artistic development took place in Copenhagen. However, Nolde regarded himself as a (Frisian) German and would become a protagonist of German painterly expressionism as a German artist in his role of member of the Dresden expressionist group Die Brücke. He maintained close relations with the border region, where he lived in the summer period on a regular basis from 1903, first on the island Als and later in the North-Frisian marshland near the Sønderå. In 1926, Nolde settled in Seebüll, only a few kilometers south of the Sønderå on the German side and became involved in German nationalist and nationalsocialist politics in the Danish governed Northern Schleswig. This did not prevent him from becoming one of the prime targets in the Nazi campaign against Entartete Kunst; in 1941 he was officially prevented from painting any more. His background played an important role in the stylisation of the expressionism of Die Brücke as a "Nordic expressionism" in the 1920s and 1930s - in contrast to the Munich-based Der Blaue Reiter with its Russian protagonist, Kandinsky (cf. Saehrendt 2005).

The expressionist poetess and cabaret artist Emmy Hennings, who was one of the key figures of expressionist Bohemian sub-culture in Munich and Berlin, co-founder with Hugo Ball of the Cabaret Voltaire in Zurich and a prominent representative of the Zurich Dada movement in 1916-17, was born in the bilingual town of Flensburg in 1885 (cf. Pust 2000/01). In her early years as an actor and variety artist, she frequently performed on stages in the German-Danish border region. Part of her repertoire as a cabaret singer was in Danish, and traces of Danish popular folklore can be found in her poetry (for instance in Cabaret Voltaire). Eggeling stayed in Flensburg for several years as well and there is a strong possibility 
that either Hennings or Eggeling directed Hans Arp towards the Danish word skypumpe (whirlwind, hurricane), which, transposed into German, became the title of Arp's Dada collection of poems: Die Wolkenpumpe (The Pump of Clouds, cf. Arp 1919, 1920).

Like Puni, neither Nolde nor Hennings can be regarded as Nordic artists, having been born German nationals, although Nolde was to receive Danish citizenship as Northern Schleswig became part of Denmark again in 1920, although he was not of Danish, but of Frisian-German, origin). The cubist and constructivist, Franciska Clausen might, on the other hand, be regarded as Nordic, having been born in 1899 in the Danish, then German, governed town of Aabenraa, and having lived and studied in her early years in Munich and Berlin before returning to Denmark in the 1930s after a longer stay in Paris (cf. Terman Frederiksen 1987-88).

\section{Avant-Garde Primitivism and the Idea of "Nordic Expressionism"}

In the early twentieth century, the revival of Old Norse and Nordic art and literature became part of the widespread avant-garde search for aesthetic renewal through primitivism. The intention of avantgarde primitivism was to recover avowedly "true", "original", "authentic" art practices and forms from all parts of the globe: so-called "negro art" from Africa and Australia, classical - often spiritual Indian, Chinese and Japanese art and literature, mystical writing from the European Middle Ages, popular art forms like reverse glass painting, everyday artefacts, European popular culture, be it in a Breton fishing village, a Bavarian or Rumanian farming community or the Yiddish culture of the shtetls in the Pale of Settlement (cf. Lippard 1983, Perry 1994, Schultz 1995). Within this framework, Old Nordic art fitted perfectly next to Byzantine and Gothic art, just as Inuit art from Greenland went side by side with songs from Polynesia and New Zealand.

As such, medieval Nordic art served as a major primitivist inspiration in the work of the Latvian painter, art critic and theoretician Voldemārs Matvejs, a member of the Russian avant-garde artist's group Soyuz molodezhi (Union of the Young). Matvejs studied medieval art on the Swedish island of Gotland in the early 1910s. His books on primitivism, published under his Russified name Vladimir 
Markov, which were quite influential in Russia, discuss medieval art from Gotland extensively (cf. Bužinska 2000).

Another example of the links between primitivism and the idea of the "Nordic" can be found in Emil Nolde's work. Nolde understood true expressionism as a "Nordic" current. This was not in reference to the geographic configuration of states referred to today as "Nordic countries" - Denmark, Sweden, Norway, Iceland and Finland - but rather related to the German conservative-nationalist assumption of the cultural and racial superiority of a ScandinavianGerman "Nordic race", as propagated - among others - by the national-socialist racial ideologue Hans Günther and socalled "völkisch" organisations like the Nordische Gesellschaft (1921-1957) that promoted the "Nordic idea", supposedly rooted in "authentic" medieval Germanic culture of Nordic provenance, in a radical rightwing context (cf. Mohler 2005). Even though the conception of a Nordic cultural unity could be found in Scandinavia as well, the distinction of a "Nordic expressionism" with a clear-cut nationalist dimension had its basis in German nationalist discourse.

Traces of this discourse could be found in the German expressionist avant-garde, in the shape of a Nordic orientated primitivism triggered by a new translation of the Edda by Felix Genzmer in the early 1920s (cf. Heusler 1920). The bureau editor of Der Sturm, the painter, poet and dramaturge, Lothar Schreyer, who led the Sturmbühne in Berlin during the war and continued his experimental theatre activities in Hamburg after the war with the so-called Kampfbühne, used a short song from the Poetic Edda, "Skírnismál", as the basis for a play (cf. Schreyer 1926). ${ }^{1}$ In Hamburg too, elements from the $E d d a$ - figures and plots - were used by the dance pair Lavinia Schulz and Walter Holdt for their productions, for which the composer Hans Heinz Stuckenschmidt created the music (cf. Rowinski 2006). At an evening devoted to atonality in the Hamburg Secession, Stuckenschmidt presented "Eddalieder" by another avantgarde composer, Hans Jürgen von der Wense (cf. Böhme 2006, Niehoff/Bertoncini 2005, von der Wense 1999: 34 and 293-315). The Edda also served as source for the Bauhaus artist Gerhard Marcks, who created an illustrated edition of the "Völundarkviða" in 1923 under the title Das Wieland-Lied, published by the Bauhaus-Verlag (cf. Marcks 1923). The revival of the Edda was undoubtedly related to the "Nordic idea". This is most obvious in the case of Schreyer, 
who was active in the "völkisch" orientated nationalist-conservative circles surrounding the journal Deutsches Volkstum and the Hanseatische Verlagsanstalt (cf. van den Berg 2010), in which not only Schreyer (1931: 48-49 and 132-145), but also Ludwig Benninghoff, the editor of the Hamburg cultural review Der Kreis, regarded early-medieval Nordic art as the cradle of a true German(ic) art that found its modern expression in expressionism (cf. Benninghoff 1924).

A further interesting example is a roman à clef by the German expressionist Hermann Essig, published in 1919 under the title Der Taifun, which related the (fictional) story of Ossi and Hermione Ganswind's (Herwarth and Nell Walden's) expedition to Iceland to study "the expressionism of the Eskimos" (Essig 1997: 235). Essig took his cue from an error in an issue of Der Sturm from the previous year, where, beside reproductions of drawings by Inuit artist Aron fra Kangek, Iceland, rather than Greenland, was given as the artist's native country (cf. Walden 1918a). In reality, the Waldens never went to Iceland, but were frequent visitors to Scandinavia. On his way back from a journey to Norway in 1911, Walden met Roslund (who would become his second wife) in the Southern Swedish town of Landskrona. However, their Scandinavian trips were not limited to family visits. As art dealers, they sought out new merchandise and opportunities to exhibit and sell their stock (cf. Werenskiold 1980), even working there during World War I as agents on the payroll of the German intelligence and propaganda apparatus (cf. Winskell 1995, van den Berg 2009).

It is significant that Walden's first trip to Scandinavia was not as a gallery owner - the Sturm Kunsthandlung was only founded after his marriage to Nell (and in part on her capital), but rather on what might be called a pilgrimage to some of the holy places of Scandinavian literature, theatre, art and music (cf. Bauschinger 2004: 170178, Lasker-Schüler 2003). Cities like Copenhagen, Gothenburg, Kristiania (Oslo) and Bergen may have been situated on the fringe of the European continent and relatively small and provincial by comparison to Paris, Berlin, Munich, Vienna, Prague and St. Petersburg, but they carried enormous prestige as cradles and hotspots of cultural progress in the last decades of the nineteenth century and the first years of the twentieth century, when Danish, Swedish and 
Norwegian writers like Ibsen, Strindberg and Brandes, and painters and composers such as Grieg and Munch were recognised internationally as pioneers of cultural renewal and modernisation (cf. Anon. 1897, Cepl-Kaufmann/Kauffeldt 1994, Henningsen 1997, Briens/ Mohnicke 2009).

Walden travelled via Copenhagen and Gothenburg to Oslo and Bergen. Oslo, or Kristiania as it was then called, was not only the home town of Edvard Munch and the city where Henrik Ibsen had been a stage director, but also a hotspot of bohemian artists. The 'Kristiania Bohemia' was well-known throughout Europe (cf. Jæger 1885, Fosli 1997), as were other Nordic artists' colonies in even more provincial settings, for instance in the Danish fishing hamlet of Skagen and on the shores of Tuusalanjärvi (Tusby träsk), a small lake north of Helsinki/Helsingfors (cf. Lengefeld 2001). The shores of Tuusulanjärvi served as a residence for Jean Sibelius, among others. Sibelius' lakeside house 'Ainola', designed by the Finnish architect Lars Sonck (cf. Korvenmaa 1991), was internationally admired as one of the finest examples of Finnish architectural National Romanticism, a major contribution to art nouveau architecture, which created an opening for modernist innovation and avant-garde experimentalism in following decades.

Walden's tour of the North may have been an exception. Most Nordic artists went South, to Paris, Berlin and other cultural centres, where Nordic artists played a prominent role in international artists' communities or established communities of their own and thus reinforced the reputation of the North as a cradle of modernist renewal.

The popularity of contemporary Nordic culture undoubtedly stimulated the interest in older Nordic culture, even in areas of the cultural field in Germany and Western Europe that were not enticed by the cult of the racist-nationalist Teutonicist "Nordic idea". Examples of this include the expressionist journal Die Aktion's printing of the first translations from the Edda by Felix Genzmer in 1913 (cf. Genzmer 1913) and Emmy Hennings' reference to the Danish popular myth of the klintekonge, a king living in limestone rock, in the poem "Gesang zur Dämmerung", published in the first Dada anthology, Cabaret Voltaire (cf. Hennings 1916).

Nordic culture's widely respected and accepted contribution to modernism was probably a major consideration behind and cause 
of the creation of an association and even an academy of Scandinavian visual artists in Paris (cf. Claustrat 1994), who exhibited collectively in the 1920s and took advantage of the "Scandinavian" label as a generally acknowledged sign of quality. And yet, while assumptions regarding the existence of some form of shared Nordic cultural identity might not have been alien to many Northern intellectuals, writers and artists - and not just for marketing reasons - primitivist appeals to ancient Nordic folklore, mythology and artefacts are not only virtually absent from, but apparently completely irrelevant to, the early twentieth-century output of avant-garde artists of Nordic provenance. In the work of these artists we find virtually no examples of the revival of of Scandinavian Viking-age heritage, as is found in the work of the German artists mentioned above, or - in later years - in the oeuvre of Danish CoBrA protagonist Asger Jorn (cf. Andersen/Nyholm 1995). The reason for this absence is probably that reference to this heritage was a major element in the hegemonic nationalist iconography of the period. Here, we find endless Viking references in Scandinavian art, while in Finland, under the banner of national romanticism which dominated the nation's cultural field around 1900, artists drew heavily on the imagery of the Kalevala, as well as on the supposedly unspoiled rural Finnishness of the Karelian woods (cf. Kuusi/Anttonen 1999, Ojanperä 2009).

To the extent that a collective Nordic identity or culture existed in the Nordic countries, it did not play any substantial role in the self-understanding of the early avant-garde in these countries as a "Nordic avant-garde". An assumed collective Nordic identity was rather used by opponents of the avant-garde. Conservative polemics directed at the avant-garde criticised the its international orientation and European character, and deemed it unfit for the Nordic context. The Finnish painter Akseli Gallén-Kallela played an interesting double role in this context. In his homeland, Gallén-Kallela was perhaps the most important exponent of Finnish national romanticism in the visual arts. His work was dominated by Kalevala imagery and representations of Finnish nature and rural life (cf. Ilvas 1996). As such, Gallén-Kallela represented the Finnish cultural field's hegemonic aesthetic values which were both opposed to and by avant-garde developments in the country. Simultaneously, unlike Edvard Munch and Henri Matisse, he accepted an invitation to join the German expressionist group Die Brücke (cf. Wietek 1985: 48-60). 
To the extent that primitivism was a part of the aesthetic repertoire of Nordic avant-garde artists, it neither drew upon still-existent native rural popular culture nor upon ancient Nordic literature and art (with the exception of Per Lagerkvist's Ordkonst och bildkonst from 1913, in which the new avant-garde poetics - based on cubist aesthetics - is linked to the tradition of Edda poetry as a source of inspiration).

\section{Avant-Garde in the Nordic Countries}

Most of this book is devoted to the dissemination and recovery of the avant-garde in the Nordic countries as well to the wider cultural field's (often negative) response to avant-garde manifestations in these countries. The book focuses on Nordic initiatives - whether led by individuals or groups and centered on journals, galleries or theatres - that took up avant-garde developments from other parts of Europe, principally France, Germany and, to a lesser extent, Russia. Partly these new developments were presented by international art merchants and collectors showing their stock and collections in galleries in the Nordic countries, like Herwarth Walden and the Petersburg collectors Sergei Shchukin and Ivan Morozov (cf. Beeren 1992, Benson 2002, Lahoda 2006). Partly they were promoted through publications - journals, pamphlets and books - that circulated internationally and in the Nordic countries as well, like Der Sturm or, for example, a book like Du "cubisme" (1912) by Albert Gleizes and Jean Metzinger. Partly they were imported by local artists, art dealers and critics. Nordic artists who made extended visits to the major avant-garde centres, such as Hjertén, Grünewald, Heiberg (cf. Cohen 2001) and the Icelander Jón Stefánsson (cf. van den Berg 2006b) - all of whom studied at Académie Matisse in Paris - returned to their homelands eager to put their firsthand knowledge of the latest vanguard trends to use.

While the Danish journal Klingen and the Swedish review flamman clearly illustrate how foreign equivalents were emulated or adapted, the Norwegian painters Heiberg and Henrik Sørensen managed to attain a solid position in their home country as painters of a modified modernism with neo-classicist tendencies that claimed to represent genuine Norwegian national values (and blocked the local recognition of more radical cubist and constructivist avant-garde 
painters like Thorvald Hellesen, Kaarbø, Keyser and Wankel as representatives of a presumedly alien international art, cf. Sørensen 2010). Similarly, the Finnish painters of the November Group received their education and orientation from abroad - from Paris and Petersburg - but managed to position themselves in the Finnish artistic field as representatives of true painterly Finnishness. Local cultural practices were complemented by new impulses through imported avant-garde aesthetics: on the other hand, imported avantgarde practices were provided with a specific couleur locale, as they were combined with local cultural particularities, sometimes literally by the use of specific colours, as in the case of bright blue in Scandinavian expressionist painting, which followed a local painterly preference for this colour (cf. Kent 1987, 1990). Similarly, grey tones dominate the work of the painters of the Finnish November Group, intended as an adaptation of their colour scheme to local preferences (cf. Koja 2005).

In the hands of progressive Nordic artists, divergent avant-garde 'schools' such as fauvism and cubism, expressionism and futurism were frequently amalgamated into hybrid syntheses that ran the risk of blurring the radical programmatic novelties through which the different '-isms' sought to distinguish their projects from one another. These Nordic hybrids often underlined the obvious commonalities between the different approaches that were overshadowed in their home territories by the polemics of the competing protagonists. Nordic artists also developed new methods and combinations that would later make an impact on the major avant-garde centres, the Danish share of CoBrA being a notable example (cf. Stokvis 1980). The first section in this volume also draws attention to the impact which the preceding generation of Nordic artists had on the historical avant-garde. August Strindberg and Edvard Munch, for example, were not only representatives of the so-called Scandinavian 'modern breakthrough' which paved the way for the international avant-garde, but also provided valuable orientation for innovative artists within this emergent avant-garde. Asta Nielsen, the Danish prima donna of early film, performed a similar function, becoming a favourite persona in early European avant-garde poetry as an icon of modern culture. 


\section{The Avant-Garde as a Network}

What we now tend to call the historical or classical avant-garde was marked by heterogeneity and a considerable degree of incoherence. Stylistically, we find extreme diversity, ranging from figurative representation descended from the European tradition of mimetic realism, as in the case of fauvism (also known as "French expressionism" in the Nordic countries, cf. Werenskiold 1984) to abstract imagery of constructivist provenance, from common prose and traditional poetic forms to free verse, image and sound poetry, from neo-classical and impressionist music to jazz and atonality, from conventional choreography with a modern design to free expressionist dance, and from classical painting to photographic and cinematic experiments. Between and within the programmatic avant-garde isms, artists frequently held divergent and incompatible opinions regarding such topics as the political function of art - we find views ranging from the radical left to the extreme right, from transnationalism to nationalism - and whether art should be understood as an autonomous phenomenon governed by its own laws or as an integrated element of society. Avant-garde groups sought to be innovative and to pursue the new, attempting to integrate into their modern aesthetic the latest scientific discoveries and technological inventions, be they the law of relativity, the discovery of the unconscious, the invention of the automobile and aeroplane, the development of electricity and telecommunication, or photography and cinema. And yet, earlier styles also served as major sources of inspiration for many of these artists. These include prehistoric and Byzantine art, as well as the fusion of arts and crafts found in the architecture and building process of medieval cathedrals (cf. Källström 2000). Indeed, the early programmatic statements of the Bauhaus provide evidence of a similar orientation towards the medieval past and towards the fusion of high art and practical design in the English Arts and Crafts Movement around William Morris and John Ruskin, as well as in turn-of-the-century art nouveau, e.g. in the architecture of the Belgian Henri Van de Velde and Victor Horta, the Vienna Secession, the Latvian Mikhail Eisenstein (the father of the film maker) in Riga and in Finnish national romanticism. Like Morris, who drew on traditional English architectural features, the latter included elements of popular, everyday rural construction from Finland and Karelia in their designs.

Despite this heterogeneity, we can observe a strong sense of unity 
pervading the classical avant-garde. This solidarity is visible in the comprehensive surveys of the period, authored by major representatives of the avant-garde, such as Herwarth Walden's Einblick in Kunst (1917), Theo van Doesburg's "Revue der Avant-Garde" (192122), Hans Arp and El Lissitzky's Isms of Art (1925) and Lajos Kassák and László Moholy-Nagy's Buch neuer Künstler (1922), and in the wide range of different approaches which can be found in major avant-garde journals of the period. Periodicals like Der Sturm, De Stijl, The Little Review, Zenit, Noi and Ma not only promoted the various projects and positions of their respective editors, they also served as platforms for the vanguard isms in general, often directing attention to other groups, initiatives and publications. The name of an association linked to the 'expressionist' Der Sturm is telling: "Internationale Vereinigung der Expressionisten, Kubisten und Futuristen e.V." (cf. van den Berg 2000). A survey of the exhibitions held in the Berlin Sturm gallery and those organised by Der Sturm in other countries, also in Scandinavia and Finland, reveals that - to all intents and purposes - the organisation represented the complete range of avant-garde isms, from fauvism and expressionism to constructivism and Dada (cf. Brühl 1983, Pirsich 1985, 2000, Reidemeister 1962). However, to acknowledge the solidarity among the various groups is not to deny their many confrontations, polemics, feuds and mutual dislikes, motivated sometimes by egotism or personal conflict, sometimes by genuinely unbridgeable differences in vision, aim, aesthetics and style.

To describe this pluralist unity, one might define the avant-garde as a project, as Wolfgang Asholt and Walter Fähnders did in their preface to Die ganze Welt ist eine Manifestation (1997: 1-17), elaborating on Peter Bürger's Theorie der Avantgarde. As they suggest, the avant-garde can be understood as a project similar to Jürgen Habermas's Projekt der Moderne (cf. Habermas 1990), not as a completed unity, but rather as an enterprise that still has (or, in the case of the early avant-garde, still had) to be completed. As such, the project is rather a configuration of fragments that were still partially isolated and incompatible, yet as fragments pointing toward a future unity to come (cf. Fähnders 2000). This configuration could be viewed as what Félix Guattari and Gilles Deleuze (1976 and 1980) term a "rhizomatic entity" or what Antonio Negri and Michael Hardt (2000 and 2004) call a partially cohesive, but above all, heterogeneous, di- 
verse and noticeably incoherent "multitude". From a socio-historiographical point of view, the avant-garde may be profitably thought of as a non-hierarchical network structured around several nodes wherein various lines converge. This network was simultaneously marked by rips, rents and ruptures. In short: the avant-garde can be seen as a heterogeneous, hybrid and multiple entity, which as a set of fragments constitutes a project in the sense of a common enterprise still to be realised.

The cohesion of this far from unified enterprise can be traced to the relations and links connecting the single isms, projects and artists as well as to the meeting points and occasions on which the so-called historical avant-garde manifested itself in a collective way. It surfaces in the lines and nodes of the rhizomatic network as a nomadic, deterritorialised locus communis, as well as in a mutual feeling of communality (cf. van den Berg 2005a, 2006a). This sense of belonging to a larger entity was seldom called "avant-garde" by those involved, but rather presented as endeavours in pursuit of "new art", "young art" or "modern art", as "isms of art" or by way of a pars pro toto, as "expressionism" or "futurism" as overarching labels. Practically, the network is visible in collaboration between avant-garde artists with divergent backgrounds, contributions in (collective) reviews, magazines, anthologies or book form surveys, at joint conferences, exhibitions, in collective projects such as publishing houses, in the membership of certain organisations, through collaboration in soirées and other manifestations, in the publication and subscription of manifestos and other proclamations, or in contributions to such enterprises (magazines, exhibitions etc.) by other avant-garde artists (often as a kind of mutual exchange) as well as by gallery owners and art dealers such as Daniël-Henri Kahnweiler or Herwarth Walden, who often played a key role as "impresarios" and binding agents (cf. de Vries 2001).

In the configuration of isms nowadays labelled "historical" or "classical avant-garde", such platforms and gathering points can be regarded as nodes and lines in a network in which a fluctuating mass of collaborating artists and writers would often join or be linked with one ism after another or even two or more simultaneously. Hans Arp, for example, can be found as signatory of Dadaist, elementarist, constructivist, concretist and surrealist manifestos. Although the notion of 'network' belongs more to the early twenty-first century than to 
the era of the classical avant-garde, it was not a completely alien idea to the avant-garde. Commenting on an international avant-garde meeting and exhibition in Düsseldorf in 1922, the Polish constructivist Henryk Berlewi referred to the avant-garde as a "world-wide network of periodicals [...] propagating and arguing for new ideas and new forms" (cit. in Benson 2002: 64). Likewise, the Belgian avant-garde review Het Overzicht presented a list of international contacts as "het netwerk" - the network (Anon. 1924).

\section{The Avant-Garde Network in the Nordic Countries}

The widespread diversity characterising avant-garde activity - at the level of both individuals and groups - was not absent from its Nordic manifestations. Beside the far from mainstream, but still rather conventional, work of artists such as Hjertén and Grünewald one finds, for example, an image poem like "Berlin" (1918) by the Danish poet Emil Bønnelycke, who was also involved in Copenhagen soirées worthy of comparison with those of the Dadaists. Whereas in the case of Dada several mock reports were spread detailing shooting incidents - in Zurich, Geneva (cf. Meyer 1985: 73) and Prague (cf. Kujundžić/Jovanov 1998: 44-45) - Bønnelycke actually drew a gun and used it at a literary evening in the Danish capital (cf. Jelsbak 2006: 83). The historical records show that Nordic avant-garde artists and collectives were an integrated part of the network of the classical avantgarde. References to Bønnelycke and other writers and artists associated with the Danish journal Klingen can be found on the cover of Iwan Goll's Paris brennt, published in 1921 as a pamphlet of the Yugoslav avant-garde journal Zenit, as well as in the first Estredentist manifesto of Manuel Maples Arce, published in Mexico City the same year (cf. Osorio 1988: 106-7). In Zenit we also find references to avant-garde artists and writers of the radical Danish New Student Society DNSS (cf. Subotić 1990: 27), who would later appear in Der Sturm, where one of them, Rud(olf) Broby (Johansen), was able to publish after his collection of poems Blod had been banned in Denmark (cf. Jelsbak 2006). A reference to flamman is found in Tristan Tzara's correspondence with Francis Picabia following a report in flamman on Dada in 1919 (cf. Sanouillet 1993: 524). Work by several Swedish and Danish artists as well as the Icelander Finnur Jónsson could be found in the Berlin Sturm gallery, which, in turn, brought 
avant-garde art from Germany, France, Russia and Italy to Denmark, Sweden, Norway and Finland. As students of Parisian academies, most notably those of Matisse and Léger, many Nordic artists came into close contact with artists from other parts of Europe and Northern America.

As in the rest of Europe, private galleries played a substantial role in the Nordic avant-garde network. Blomqvist Kunsthandel, for example, established in Kristiania/Oslo in 1870 and, in itself, no avantgarde enterprise, became an important platform for both Nordic and European avant-garde art, and exhibited Munch, Die Brücke, Der Blaue Reiter and Der Sturm. Munch exhibited there several times, and, in 1908, works by Die Brücke artists were shown (cf. Werenskiold 1974, 1997). In January 1914 Blomqvist presented a travelling exhibition of Der Blaue Reiter arranged by Walden (cf. Westheider 2000: 79). In 1923 works by Archipenko, Gleizes, the Belgian Marthe (Tour) Donas and Kurt Schwitters drew some five thousand visitors. ${ }^{2}$

In Copenhagen, the building of the older secessionist movement, Den Frie Udstillingsbygning, the exhibition venue of a later secessionist group of Den Frie called Grønningen, as well as the gallery of the art dealer Georg Kleis (cf. Walden 1918b,) and the artists' cabaret Edderkoppen served as exhibition spaces and meeting points for local avant-garde artists (cf. Aagesen 2002).

In Finland two Helsinki/Helsingfors-based galleries fulfilled the same role (cf. Koja 2005). Stenbergs Kunstsalong was led by the Finnish art dealer Gösta Stenberg, who represented Helene Schjerfbeck and Tyko Sallinen for many years but also stocked works by several post-impressionist colourists of the Septem group and the expressionist November Group. In 1915, Stenberg presented several of these works alongside those of the Parisian cubists Picasso and Gris, the fauvist Dérain and the Swedish expressionist Grünewald (cf. Salmela-Hasán 1994, Sarajas-Korte 1968, 1969). Founded in 1913 by the Swedish art dealer Sven Strindberg, a cousin of the famous author, Salon Strindberg's first major foreign show, entitled "Exhibition of Expressionist and Cubist Paintings" took place in February and March 1914, presenting work by the Blaue Reiter group (cf. Walden 1914), previously shown in Kristiania, as well as that of the Brücke group and other German expressionists. The exhibition was arranged in collaboration with the Berlin Sturm gallery (cf. Sarajas-Korte 1970, Westheider 2000: 80). 
Both Stenberg and Strindberg had direct contact with the Petersburg art scene, a major centre of the Central and Eastern European avant-garde, where works by French cubists with apparent similarities to those of Ilmari Aalto and other representatives of the November Group could be found in local collections. Two major Russian exhibitions took place in Salon Strindberg in 1916 (cf. Sarajas-Korte 1971, Sinisalo 1993, 1998): In spring, Salon Strindberg presented a cross-section of Russian avant-garde art featuring work by Ksenija Boguslavkaja, Marc Chagall, Aleksandra Ekster, Vasilij Kandinsky, Ivan Puni, Olga Rozanova and Vladimir Tatlin, among others. The exhibition was a result of Strindberg's close collaboration with the avant-garde Art Bureau of Petersburg art dealer Nadezhda Dobychina. In September, a Kandinsky solo exhibition followed.

\section{The Cultural Geography of the Nordic Avant-Garde}

World War I intensified the artistic exchange between Finland and Russia for a short time. Finland became a backdoor connecting the Russian Empire to neutral Scandinavia. The neutrality of the Scandinavian countries allowed traffic, travel and communication between artists of the warring states and turned these countries into a place of refuge for those seeking to escape the war, including many members of both the political and cultural avant-garde. Lenin crossed Scandinavia on his way back to Russia in 1917. Three years later, a German fishing vessel hijacked by the German expressionist and dadaist Franz Jung along with other members of the councilcommunist Kommunistische Arbeiter-Partei Deutschlands called in at various Norwegian ports before landing in Murmansk as official party delegates of the KAPD on their way to visit Lenin (cf. van den Berg 1990).

From the opposite direction, several Russian artists used Scandinavia to meet with colleagues from the West - both from Entente countries and Germany - in the neutral Northern backyard of Europe. Vassilij Kandinsky, for example, came to Sweden to meet his German wife and fellow painter Gabriele Münter in 1915-16 (cf. Kleine 1994: 453-503). After Kandinsky left her in 1916, Münter would return frequently to Scandinavia in the following years, exhibiting in Copenhagen and Stockholm, but also to lead a private summer painting school at Bornholm (cf. Kleine 1994: 502). Scan- 
dinavia also provided opportunities to escape the war in more permanent ways. For example, the brothers Naum (Gabo), Antoine and Alexii Pevsner stayed in Kristiania during the war (cf. Hammer/Lodder 2000, Nash/Merkert 1985, Pevsner 1964), while Vladimir Baranov-Rossiné became a Copenhagen resident during the same period (cf. Brusberg 1995, Kiblickij 2007), albeit without any substantial involvement in the local art scene.

These cases resemble those of Sallinen, William Lönnberg, Juho Mäkelä and Jalmari Ruokokoski and other painters of the Finnish November Group, who stayed in Helsingør, a small town not far from Copenhagen, for extended periods of time on their way back to Finland from Paris in the early 1910s (cf. Koja 2005, Ojanperä 2001). In Helsingør, they worked for and were supported by the local master tailor Niels Pedersen Rydeng. Sallinen was a trained tailor, Rydeng a collector of paintings. Although the expressionist November Group painted, by and large, in the same fauvist and cubist 'tradition' as their Danish colleagues, and although Rydeng collected contemporary Danish painting and had contacts in the Copenhagen art scene, Sallinen, Ruokokoski and Lönnberg worked in Helsingør for several years, but had virtually no contact with the art scene in nearby Copenhagen. This is indicative of the somewhat detached character of the Finnish-speaking Finnish avant-garde within the wider Nordic context. In contrast to this, we find close relations between Icelandic and Scandinavian avant-garde artists and initiatives due to a shared history, linguistic kinship and colonial dependency of Iceland upon Denmark. Likewise, close cultural relations existed between Norway and Denmark in particular. Similar cultural relations existed between the Swedish-Finnish community and Sweden as well. Thus, SwedishFinnish authors can be found in Swedish literary magazines and vice versa. Likewise, Norwegian and Icelandic artists provided an acte de présence in the Danish journal Klingen.

The Nordic avant-garde's closest international relations, however, were with European art capitals like Paris and Berlin. Thus, it seems doubtful whether avant-garde activities in the Nordic countries in this period can be understood as manifestations of a genuine Nordic avant-garde based on a clear "Nordic" identity, which would be more than a simple addition of the avant-garde presence and activity in the single countries (if some Nordic identity can be discerned at all, this seems to be primarily the case in the diasporic communities es- 
tablished by Nordic artists in cultural centres such as Paris and Berlin).

For obvious topographical and historical reasons, the connections between different Nordic artists and initiatives were closer than the relations with the avant-garde community in other parts of Europe during World War I, since traffic to and communication with the rest of Europe were very limited due to closed borders and frontlines. Nevertheless, these Nordic avant-garde artists and initiatives were rooted in and operative within their respective politically- and linguistically-defined national artistic fields. While these fields were, to some extent, interrelated, they were far from unified. As a consequence, important players in one country were virtually irrelevant and unknown in the other Nordic countries. Emil Bønnelycke and Rud(olf) Broby (Johansen), for example, were household names in Denmark's avant-garde community. But although one finds their names in Zenit and Der Sturm, they were never embraced in the other Nordic countries as major fellow Nordic avant-gardists. To characterise them as representatives of some transnational entity, which one could call a 'Nordic avant-garde', might suit present-day perceptions of the Nordic countries as forming a political and cultural unity with close cross-border relations, genuine transnational artistic projects, exhibitions and literary prizes and so on, but such a label would misrepresent the obvious dividing lines that existed between the artistic communities of the individual Nordic countries in the early twentieth century.

Common features are nevertheless discernable in the avant-garde manifestations of the Nordic countries. These do not amount to a set of uniquely Nordic characteristics, but rather to Nordic versions of peripheral avant-garde manifestations, analogues of which can be identified in other margins of the European avant-garde. The most prominent features are: apparent belatedness, moderation, and a tendency toward deradicalisation. In general, the new trends were imported from cultural capitals such as Paris and Berlin and then reproduced in native contexts, frequently in more moderate forms. One might argue that this regionalised moderate form was no less radical than the interventions emerging from the transnational arena. However, despite figures such as Bønnelycke, there can be little doubt that avant-garde initiatives in the Nordic countries predominantly toned down the radical foreign approaches in attempts to make them 
more acceptable at home. Indeed, a moderate form of expressionism based on French fauvism dominated Nordic versions of existing avant-garde models - as it did in other marginal parts of Europe (cf. Werenskiold 1984) - setting the tone in all Nordic countries from the end of the first and the beginning of the second decade of the twentieth century. This expressionism was not only moderate formally and stylistically, but also institutionally, lacking any attempt to undermine, overcome or destroy the autonomous institution of art itself - one of the basic features of the historical avant-garde, according to Peter Bürger in Theorie der Avantgarde. Against the background of the modern ideology of progress, however, this expressionism does show some elements of novelty. These elements allowed its representatives to position themselves as a new generation of artists and secure positions within the institution, the toned-down 'wild' elements directly serving this cause, albeit perhaps unintentionally. Later cubist and constructivist initiatives in the Nordic countries also lacked a dimension of institutional critique. The only exception seems to be a circle of artists and writers in Det Ny Studentersamfund (DNSS), whose activities questioned the institutional autonomy of art through their attempt to bring art and politics together.

The specific geographical position of the Nordic countries, and their distinctive (often uninhabited) landscapes, nature, climate and light made a noticeable impact on Nordic art, the avant-garde included; as did the relatively small scale of urbanisation and the endurance of strong rural communities well into the early twentieth century. The countryside has a strong presence in Nordic avant-garde art. War, however, plays only a minor role. The Nordic countries' experience of war and revolution differed markedly from that of most other European countries. In comparison to the majority of European avant-garde art and literature from the period, the traces of war and revolution in the works of the Nordic avant-garde are few. It was not until the Finnish civil war of 1918 that bloody conflict impinged directly on Nordic life. War and revolution did eventually become subjects addressed by avant-garde writers and artists in the Scandinavian countries, most notably among the Danish expressionists of the DNSS, but on a limited scale. In Finland one could have expected a stronger presence. Yet, a period of repression against leftwing politics and anything suspected of being communist following 
the 'white' civil war victory limited possibilities for Finnish avantgarde initiatives considerably.

\section{The Nordic Countries in the Early Twentieth Century}

Avant-garde artists and initiatives in the Nordic countries did not constitute a single cohesive Nordic avant-garde. Nevertheless, within the Nordic countries relatively close relations did exist among artists, writers and performers of different nationalities. These relations were partly a result of their joint stays in Paris, by and large as students, and partly a result of close cultural ties and shared histories (cf. Derry 1979, Gustafsson 2007, Kent 2000, Klinge 1995). Denmark, Norway and Sweden have cognate languages, Swedish is spoken by a part of the Finnish population and Danish was the language of colonial rule in Iceland. Whereas Iceland remained a part of the Danish empire until 1944, Norway became independent from Sweden in 1905. Due to Danish rule until the early nineteenth century, close contacts existed between Norway and Denmark, at least in the cultural sphere. The fact that the Scandinavian countries remained neutral during World War I (unlike the Grand-Duchy of Finland, which, as a satellite of the Russian tsarist empire since 1806, entered the war on the side of the Entente) allowed Copenhagen to become a substitute for Paris and Berlin during this period when the French and German capitals were difficult to reach due to the closed borders and frontlines.

Copenhagen, due to its Southern location, had served as a passage for Scandinavians on their journey to Europe South of the Baltic Sea (at least since the opening of a railway connection from Helsinki to Petersburg; another route via the Russian Empire was available for Finns). Due to its role as colonial capital, Copenhagen had also been the first stop for Icelanders on their way to Europe for a much longer period. The city's role during the war as gathering point for Nordic artists, not least those of an avant-garde provenance, is evident, for example, from the different Nordic nationalities assembled within the pages of the journal Klingen.

Yet, whereas the Nordic countries might nowadays be seen as a kind of supranational political entity cooperating in the Nordic Council, to some extent as a counterpart of or alternative to the European Union (in which only Finland participates in full), Northern 
Europe was still marked by several deep divisions and differences in the first decades of the twentieth century. Iceland had a special status as a colony of Denmark in the middle of the Northern Atlantic, with a distinctive, yet kindred language to the other North-Germanic languages spoken in Scandinavia (cf. Karlsson 2005). In an age of emerging nationalisms, the different background and character of Icelandic society and culture stoked growing dissatisfaction with its colonial status alongside its aspirations for greater autonomy and independence. These factors constituted a fertile breeding ground for Icelandic nationalism, which fostered and defended its 'own' Icelandic culture against alien influences. From the beginning of the 1920 s, this played a large role in the hegemonic attitude towards the 'foreign' international avant-garde. In Norway (which regained its independence more or less simultaneously with the first manifestations of the avant-garde) nationalist discourses were celebrated for discerning true Norwegian culture from foreign influences and they presented a climate in which the transnational avant-garde met considerable opposition.

The political situation in Finland demands a more detailed description. Finland had a history of its own and, to a large extent, a unique cultural background in the Nordic context (cf. Sauvageot 1968). As noted, a part of the Finnish population spoke and still speaks Swedish due to long historical - political, social as well as cultural - ties with Sweden, to which Finland belonged from the late Middle Ages until 1809, when it became an autonomous GrandDuchy within the Russian Empire, gaining independence only after the Russian Revolution in December 1917. Swedish-speaking Finns are a minority, although they have a strong presence in the intellectual elite. The majority of inhabitants spoke and still speak FinnoUgric languages: Finnish, Karelian and Sami. As in Sweden and Norway, where Sami is also spoken in the Northern part, Lappland, the Sami played no role in Southern cultural life, to say nothing of its avant-garde fringes - with one exception: the Sami John Savio from Bugøyfjord near Kirkenes adopted expressionist elements in his wood-cuts of the 1920s. However, he never acquired a position in the Norwegian art scene (cf. Nerhus 1982).

In Finland, next to Swedish spoken by sections of the establishment as well as in rural and coastal areas in the South and West and Sami spoken in the North by the nomadic 'Lapps', Finnish was (and 
is) the language of the majority of the population, who also have their own distinct cultural features, traditions and ethnic background that partly differ from those of Scandinavia.

After becoming part of the Russian Empire, Finland endured concerted attempts at Russification by the tsarist regime in the late nineteenth and early twentieth century. Partly in reaction to this Russification policy, and partly as a local manifestation of the nationalist sentiment spreading throughout Europe coupled with an emergent self-understanding of being a nation in its own right, Finnish nationalism rose to prominence with ancient Finno-Ugric oral poetry and folklore as cultural capital of its own, epitomised by the 'national epos' Kalevala, constructed by Elias Lönnrot in the early nineteenth century in line with the Herderian approach to popular poetic traditions. The more radical, politically conservative manifestations of Finnish nationalism were directed not only against the colonial policies of the Russian Tsar, but also against Swedish/Scandinavian cultural hegemony. This unique set of circumstances is also reflected in Finnish avant-garde history.

Whereas Swedish-speaking Finnish writers participated in Swedish literary life, and even played a precursory role in the development of an avant-garde poetics ${ }^{3}$, Finnish-speaking expressionist artists had virtually no contact with their Scandinavian counterparts. This is most dramatically visible in the case of the Finnish-Finnish November Group members who stayed in Helsingør in the early 1910s without participating in the Danish artistic field (see above). There may well have been some interaction, but if there was it remains undiscovered, and the general impression is that the Finnish painters lived separate lives. When their work was shown following the war and Finnish independence, as part of the Finnish contribution to an exhibition of Nordic art in Copenhagen in 1919, the divide was further reinforced by Scandinavian critics who - in line with Svecoman racism - considered the work of the November Group as indicative of a different, inferior race.

The considerable divide between Finland and the Scandinavian countries was not only a result of a century under Russian rule, but also of the experience of revolution and civil war, which tore the country apart immediately after its independence in the first months of 1918 (cf. Ylikangas 1993). Although the Finnish independence proclaimed by the nationalist majority of the Finnish senate was ac- 
cepted by the new Russian bolshevist regime in December 1917, a civil war between 'Reds' and 'Whites' followed in January 1918. Opposing armies were formed, with the Red Guards (Punakaartit) and Workers' Defence Guards (Työväen järjestyskaartit) on the left, and the 'White' Protection Corps (Suojeluskunnat) on the right. Initially, the 'Reds' controlled most of Southern Finland, with strongholds in urban industrial centres such as Helsinki, Turku, Tampere and Viipuri. The 'Whites' controlled Northern and Central Finland, and chose Vaasa as the provisional home of the conservative government, which had a well-organised army led by experienced officers at its disposal and received assistance from German army units. As a consequence, the Red Guards were not able to keep their positions and suffered a major defeat in a large battle in Tampere in late March/early April. Later that month, the 'Whites' scored another victory in Viipuri, while the intervention of the German so-called Baltic Sea Division in Helsinki led to yet another 'Red' defeat. Consequently, the Reds were forced to surrender, flee to Russia or go into hiding. On 2 May the conservative government was able to return to Helsinki, and by 15 May, all Finnish territory was under control of the 'White' army.

The war was followed by a period of 'White' terror intended to suppress the remaining Finnish socialists and communists, many of whom were executed, interned in prison camps or chased out of the country. During the war, some 4,000 'White' and German soldiers and some 6,000 Red Guards and Russian soldiers were killed on the battlefield. The Reds executed some 1,500 opponents, while over 20,000 Reds were executed or died in prison camps, where a total of 80,000 people were interned. The civil war created deep, long-lasting divisions within Finnish society and a permanently tense relationship with Bolshevik Russia. Together, the 'White' conservative government that ruled Finland from May 1918 and the conservativenationalist cultural elite promoted an anti-Russian attitude that openly rejected anything communist. Finland's problematic relationship with tsarist and later Soviet Russia also had an impact on the reception of art and literature of avant-garde provenance.

Whereas Swedish-Finnish literary circles remained at the forefront of poetic experiment and innovation during the inter-war period, albeit as a Swedish enclave in Finland, many Finnish nationalists considered avant-garde art to be intrinsically Russian 
and, more specifically, Bolshevist. This opinion - not uncommon in the other Nordic countries, but especially pronounced in Finland was actually borrowed from German conservative and right-wing nationalist criticism that coined the term Kulturbolschewismus, or cultural bolshevism, to describe any vanguard art which they felt did not conform to their programme. In a way, this opinion was confirmed in the Finnish context by the fact that Otto Ville Kuusinen, the ideological leader of the Finnish Soviet Republic, was very much interested in avant-garde literature and was a close friend of Elmer Diktonius, one of the protagonists of Finnish-Swedish avant-garde poetry (cf. Henrikson 1971).

\section{Under the Lee of the "Modern Breakthrough"}

The marginality of Nordic activity in general accounts of the classic avant-garde can be traced back to several factors. Firstly, there is the simple quantitative condition that, since the Nordic countries are sparsely populated, their artistic fields have been very small. Iceland, for example, had a mere 85,000 inhabitants in the early 1910s, and its avant-garde artists could be counted on the fingers of one hand. Another factor might be that no major manifesto of the classic avantgarde was authored by an artist or writer of Nordic provenance. ${ }^{4}$ The only notable exception to this rule is Viking Eggeling. However, his contributions can hardly be tied to a Nordic context. Eggeling was one of the signatories of the dada-related Radikale Künstler group's manifesto which appeared in the spring of 1919. Indeed, he was probably its author, judging by discussions documented in the Marcel Janco archive (cf. Seiwert 1993: 561-577, van den Berg 1999: 380-390). Eggeling was also co-signatory with Raoul Hausmann of the "Second Presentist Manifesto" published in 1923 in the Hungarian review Ma (cf. Asholt/Fähnders 1995: 300). However, Eggeling's crowning glory - in terms of manifestos - appears to have been a statement on universal language, written, at least in part, with Hans Richter and published in 1921. Unfortunately, the manifesto appears to be lost, although Eggeling did publish what seem to be extracts in $\mathrm{Ma}$. Given that Theo van Doesburg referred to the manifesto as a key text of constructivism, it seems reasonable to speculate that had the manifesto received a wider distribution, Eggeling would have attained the status of a major programmatic spokesman of the avant-garde. 
But there is more. The presence of the classic avant-garde in the Nordic countries, its historical organisational structure and artistic production as well as its historiography, were not only determined by the political, social and cultural factors outlined here, but also by other particulars, partly, perhaps, unique to the Nordic countries, but also partly to manifestations of the avant-garde not uncommon outside the main centres of avant-garde activity in Europe.

As previously noted, the whole range of avant-garde art - from moderate fauvism to radical non-objective, abstract art, from free verse to visual and sound poetry - can be found in the Nordic countries (with radical practices occupying a much smaller space than more moderate forms). Most art produced by the classical avantgarde in the Nordic countries may be different from locally produced mainstream art, but is nevertheless not marked by a drastic rupture with hegemonic artistic conventions. Avant-gardism in the Nordic countries - as in other peripheries - seems often to have a rather diluted character, without (or almost without) any of the radical antagonistic edge typical of the main manifestations of the avant-garde as we know them from Paris or Berlin. This can be explained in different ways. To some extent small innovations may have been already radical enough to achieve an avant-garde status. Small deviations from the ruling norms may also have been as far as an artist could afford to go without risking the loss of buyers for his or her work or publishers for his or her texts. The moderate wing of the avant-garde may have been (and was in fact) much larger in the cultural capitals of Europe, as demonstrated by the case of the École de Paris and cubism à la Gleizes and Léger compared to - say - Parisian dada, constructivism or surrealism. Yet, with the larger overall presence of the avant-garde, the radical wing could still make a far more substantial impression in Paris than for example in Copenhagen or Stockholm, not to speak of the pocket-size cultural scenes in Kristiania/Oslo, Helsinki and Reykjavík.

Undoubtedly, the prevalence of moderate avant-gardism in the Nordic countries makes an even weaker impression when compared to the historical claims (and ambitions) of protagonists of the classical avant-garde such as Marinetti, or compared to the historiographical hypotheses drawing on these claims. Influential theoretical models like Peter Bürger's Theorie der Avantgarde thus claim that the avant-garde was essentially characterised by a dramatic and funda- 
mental rupture with existing art practices and the ambition to overcome art as an autonomous institution, even though recent research has pointed to the fact that even the most radical movements of the avant-garde were characterised by far more conventialism and traditionalism than the avant-garde historiography of the past decades suggests. The fact that the Finnish painter Akseli Gallén-Kallela was invited to join the German Brücke might support Bürger's suggestion that Die Brücke was anything but avant-garde (cf. Bürger 2005). Since Die Brücke was an integrated part of the historical network of the classical avant-garde in the years before World War I, GallénKallela's invitation indicates that the rupture with the art of previous generations (to which Gallén-Kallela definitely belonged) was not as radical as often assumed.

Here, another factor should be taken into account. Despite its diminutive size, the Nordic cultural field had been enjoying a comparatively large international reputation since the late nineteenth century, in literature, theatre, visual art, music and architecture. Henrik Ibsen, Bjørnstjerne Bjørnson, Alexander Kielland, August Strindberg, Georg Brandes, Holger Drachmann, Gustav Vigeland, Edvard Munch, J.P. Jacobsen, Herman Bang, Edvard Grieg and Jean Sibelius were not only Nordic household names, but major figures lending impetus to European letters, arts, theatre and music. For many years, what Georg Brandes called the Nordic "modern breakthrough" (cf. Brandes 1883, Ettrup 1993) remained at the forefront of international literary, artistic and musical innovation.

Similarly, the architecture of Finnish National Romanticism combining modern building with (supposedly) traditional elements, drawing on local material and stylistic features and integrating nationalist imagery based on the Kalevala and Finnish-Karelian folklore in its ornamentation - was generally recognised as an important contribution to international art nouveau that paved the way to avant-garde architecture in the following decades. Next to Victor Horta, Henry Van de Velde and Mikhail Eisenstein, Finnish architects like Herman Gesellius, Armas Lindgren and Eliel Saarinen as well as Lars Sonck enjoyed international reputation as innovative architects and designers. Like Sonck, in his design of Sibelius' house, Gesellius, Lindgren and Saarinen were higly respected for their home-studio Hvitträsk in Kirkkonummi/Kyrkslätt near Helsinki, the Suur-Merijoki estate near Viipuri on the Karelian Isthmus and the 
design of the Finnish pavillion at the Paris World Exhibition in 1900. These projects were landmarks of the art nouveau ambition to combine different arts and crafts in a new architecture intended as a total work of art. Saarinen's design for the Helsinki central station and a comprehensive expansion of the city in the so-called MunksnäsHaga Plan turned Helsinki into a major site of modernist architectural innovation (cf. Amberg 2003, Komonen 1986, Pallasmaa 2006).

One could qualify the guiding role played by Nordic artists, writers, composers and architects in the late nineteenth and early twentieth centuries as avant-garde, in terms of both Renato Poggioli's Theory of the Avant-Garde (1968), which suggests a general avantgarde inclination in modernism as such, and in terms of studies that situate a first wave of avant-gardism in the late nineteenth century (cf. Datta 1999, Frascina 1993, Hepp 1987).

Indeed, one can observe in the writings of Georg Brandes, for example, that some sense of avant-garde self-understanding (usually articulated through such labels as "new", "young", "youngest" and "modern", which remained popular in the following decades as well) was not alien to the idea of aesthetic modernity in the Nordic countries in the late nineteenth century. Actually, Brandes used the label 'avant-garde' as early as 1872 (Brandes 1901: 174):

What is as distressing as the deep gorge, brought about by the avantgarde's all too rapid advance, and the least privileged classes being barred from all higher culture, which has appeared between the learned and unlearned in all peoples and what is more natural and better than the all-powerful scientist and the artist who forcefully let go of their scholarly sophistication and get accustomed to, if possible, adopting emotions and thoughts of the simplest and most easily understood forms? But should one thereby forget, that the road is uphill, always uphill, that "excelsior" is the watchword, as it is termed in Longfellow's wonderful poem, and is there reason in the attempt to call back the avant-garde in order to not exhaust those lagging behind or even wanting to cut it down so that the whole army can stay together? ${ }^{5}$

Brandes' remark sounds a persistent note in the conceptual history of the avant-garde by foregrounding the term's transposition from its military origins to the cultural field. Brandes combines this with 
the notion of a linear, progressive, 'upward' cultural movement - a common feature of nineteenth-century cultural teleology echoed in the label "avant-garde" which endures to this day, despite all postmodern doubt.

It is also obvious that Brandes does not use the term "avantgarde" to refer to the specific set of movements or currents within or supplementing aesthetic modernity, which we now tend to call '(classical) avant-garde', but, rather, to a general cultural trend or, more precisely, a typical late nineteenth-century cultural pattern of expectation towards a course of history marked by a gradual progressive development towards a higher stage of human culture, which, according to beliefs widespread at the time, can be attained through utopian concepts of the Enlightenment and philosophical idealism. These utopian ideas held that (cultural) education, the growth of knowledge and insight would bring about a better humanity, society, life and world. Brandes' remarks regarding scientists and artists seem to echo the nineteenth-century utopian-socialist conceptions of an intellectual avant-garde in the service of revolution. This notion can be found as early as 1825 in a dialogue written by the Saint-Simonist Olindes Rodrigues entitled "L'Artiste, le savant et l'industriel" (cf. Calinescu 1977: 103), and later, in the anarchist Petr Kropotkin's appeal "Aux jeunes gens", published in 1880 in the journal Le Revolté, in which he criticises the l'art-pour-l'art trend, and demands of artists, writers and intellectuals: "Place your pen, your chisel, your ideas at the service of the revolution [...] take the side of the oppressed" (1970: 273, 278).

Brandes seems to articulate some reservations about a subjugation of the artistic and scientific avant-garde to the political banner of revolution, just as he does about a lowering of aesthetic or intellectual standards to meet the tastes of the masses lagging behind. One might argue that he leans towards the later notion of the historical avant-garde as an autonomous force detached from a following army (cf. van den Berg 2009: 26-27). In his later writings, Brandes was, however, unequivocal in his rejection of the historical avantgarde and much closer to György Lukács' defense of classical form. In an essay on the future of European literature, published in 1921, Brandes criticised "Formens Opløsning" (the dissolution of form) (cit. in Sørensen 2004: 187) in Strindberg, as well as in futurism, cubism, expressionism and dada, referring to Filippo Tommaso 
Marinetti, Der Sturm and the dadaists Philippe Soupault and Tristan Tzara as representatives of an all-too-individualist direction without any future.

If we understand the classical avant-garde as a network, it is unsurprising to find that the beginnings of the avant-garde and the tail end of the "modern breakthrough" overlap to some extent. Herman Bang and Georg Brandes, for example, can be found in the early volumes of Der Sturm, while Strindberg served as a major point of reference in German literary expressionism and beyond, much like Munch, who was not just present in the Sturm gallery, but provided direction for many early avant-garde painters in Germany and elsewhere (cf. Głuchowska 2009). Ibsen's En Folkefiende (An Enemy of the People) was mentioned in the same breath as Nietzsche's Also sprach Zarathustra; such works served as beacons for an avantgardism swimming against the tide or standing on some rocky outcrop looking toward a distant future. Avant-garde or not (and in terms of the classical avant-garde as a network, not), authors such as Bang, Brandes, Ibsen and Strindberg, who clearly belonged to previous generations, overshadowed subsequent avant-garde activity in the Nordic countries, not least because of its predominantly moderate, derivative character. Thus, the Nordic avant-garde experienced difficulties in escaping the shadows of its powerful predecessors. The Paris-based Ballets Suédois (1920-25) and Association des Artistes Scandinaves à Paris (responsible for exhibitions of little-known Nordic artists in the Maison Watteau in the years 1923-1925) attempted to turn this challenge to their advantage by drawing on the heritage of the Nordic "modern breakthrough".

Not only in the early twentieth century, but also in later historiography, the Nordic avant-garde artists were placed under the lee of the "modern breakthrough". With the emergence of the Anglophone label "modernism" as an umbrella term capable of encompassing avant-garde developments (cf. Bradbury/McFarlane 1978, Eysteinsson 1990, 2008, Eysteinsson/Liska 2007), Nordic involvement in the early avant-garde remained invisible for many decades, no longer simply overshadowed by the "modern breakthrough", but also by more recent post-World War II avant-garde developments, in which artists from the Nordic countries attained more important, even central, roles in the international avant-garde as a whole. Starting with the Danish share of CoBrA - understood by those involved as an 
avant-garde venture - which eventually relocated to the Situationist International, and flanked by the substantial contribution of Swedish writers to the rise of concrete poetry, several Nordic writers, painters, sculptors, musicians and artists from other disciplines played a prominent role in the European and global avant-garde of the second half of the twentieth century. Several Nordic hot spots of avant-garde activity have emerged in the past half century too, including Drakabygget, Moderna Museet and Iceland, the chosen working place of the Swiss-German artist Dieter Roth.

\section{The Advance of "Avant-Garde" as a Label}

As Paul Wood (1999: 10) has pointed out, it was only after 1945 (or rather, in the 1950s and 1960s) that avant-garde became a more common label for artists, movements, currents and trends concerned with innovation, experiment and radical change, not only of art itself, but also of the status of art within society and, in many cases, of society as a whole. The post-World War II avant-garde consciously adopted this label, abandoning the terms that had dominated the first half of the century, such as "new", "young" and "modern":

"Avant-garde" became pervasive as a synonym for "modern art" during the boom in culture after World War II. But many of the movements it is loosely used to refer to predate World War II by several decades, and at the time when they first flourished, the term "avantgarde" was not nearly so often used to describe them. [...] The concept [only] achieved a kind of dominance or "hegemony" in the period from about 1940 to about 1970. [...] In artistic terms, these were the decades in which a conception of artistic "modernism" was consolidated, whose most important centre was New York. Modernism, as a specialised critical discourse in art, declined in influence after about 1970, but in wider and less specialised thinking about art during the years since, the term "avant-garde" carried on bearing the meanings it assumed then, and to an extent it continues to do so. "Avant-garde", then, became not just a synonym for modern art in the all-inclusive sense of the term, but was more particularly identified with artistic "modernism", and hence shorthand for the values associated with that term. 
In other words, the classical avant-garde was labelled as avant-garde through posthumous historiography - a fact revealed by use of epithets such as "classical" and "historical". These epithets not only suggest a degree of historical distance, they also imply the existence of another, contemporary avant-garde from which the earlier incarnation must be distinguished.

It should be added here that the more widespread introduction and circulation of the label avant-garde in the European and global cultural field in the second half of the twentieth century was not adopted by all languages or (national) historiographies at the same time and to the same extent. This Ungleichzeitigkeit (un-simultaneity), to use a term by Ernst Bloch, is certainly characteristic for the dissemination of avant-garde as a fixed historiographical label and concept in the Nordic countries. Avant-garde as an umbrella term for innovative aesthetic developments, with its continental European background, rooted in French cultural discourse (and from there with a longer tradition in Spanish and Italian settings) might have already entered cultural discourse in the Nordic countries on a sporadic basis in the first half of the twentieth century and might be observed more frequently in criticism and programmatic texts after 1945.

Yet, if book titles give some indication of the circulation and popularity of labels like avant-garde, the real breakthrough of the term avant-garde as a historiographical category in the Nordic countries can be dated back to 1974 - the same year in which Peter Bürger's seminal Theorie der Avantgarde was published. One year before Bürger's Theorie, a catalogue from Liljevalchs konsthall and Göteborgs konstmuseum was the first Swedish book to mention avantgarde in its title (Anon. 1973). In 1974, the first volume of a book series edited by Kela Kvam, Europaisk avantgarde teater 1896-1930, appeared in Denmark. Five years later, the catalogue accompanying a 1979 Norrköpings Museum exhibition (Lalander 1979) was the first Swedish book devoted to the Swedish avant-garde (named as such).

In Denmark, it was not until the early 1990s that the term avantgarde was applied to Danish art in the title of a book, in a small brochure published by Statens Museum for Kunst (The National Gallery of Denmark) (Würtz Frandsen 1993), although the term had already appeared in a subtitle thirteen years earlier (Loesch 1980). 
The first major publication on this topic was a 2002 catalogue from the same museum (Aagesen).

In Finland, the term avant-garde was first used in a book title in 1986 of a catalogue of Russian avant-garde art. Subsequently, the term was used exclusively in connection with the Russian avant-garde for a number of years (cf. Siivonen 1992). In 1996, two scholarly publications appeared that were devoted to the Finnish (neo-)avantgarde in music and theatre, depicting these currents as such (Rautiainen 1996; Nurminen 1996). Until today, there is no monograph of the early Finnish avant-garde that uses avant-garde or the Finnish equivalent, etujoukko, in the title.

In Norway the first book to use avant-garde with reference to the aesthetic avant-garde dates from 1987 (Sandberg). The first study devoted to the Norwegian avant-garde and written in Norwegian to explicitly refer to the concept in its title was an MA thesis from Oslo University (Mørch 1993). There exists no comprehensive general monograph of the early Norwegian avant-garde with the word avantgarde in its title.

The first Icelandic book to use framúrstefna, the Icelandic equivalent of avant-garde, was a collection of European avant-garde manifestos published in 2001 (cf. Hjartarson/Eysteinsson/Árnason 2001), preceded by a 1997 MA thesis from Háskóli Íslands (Hjartarson 1997). There is no book covering the Icelandic avant-garde with framúrstefna in its title.

As noted at the outset, scholarly books and articles on single Nordic avant-garde currents and artists have been published in all Nordic countries - often without avant-garde appearing in the title. Thus, the preceding overview should not be taken as nominalistic proof that the avant-garde has been almost completely ignored in this part of the world. The purpose of this overview is to show how the label, category and concept of avant-garde have been virtually absent from most historiographies of the arts of the Nordic countries until quite recently. This fact self-evidently has some major consequences for and coincides with an apparent absence of avant-garde historiography in the Nordic countries. This is most obvious in Norway, Finland and Iceland, where avant-garde has only become a recurrent term in twenty-first century cultural histories. Historiographical emphasis on the wider category of modernism has meant that organisational structures and aesthetic practices belonging to 
the network and manifestations of the classical avant-garde - including its peripheral fringes - to which Nordic branches contributed, have long remained invisible, and are only now coming into view.

To the extent that the modern and modernism have been the dominant terms used to focus and describe the avant-garde in the wider context of twentieth-century arts and letters, the prevalence of modernism frequently concurred with the assumption of an absent or at best - sporadic, almost negligible avant-garde activity in the Nordic countries. As this volume shows, an application of the avantgarde lens to the scrutiny of the more progressive elements of Nordic culture around the turn of the twentieth century can facilitate the retrieval of contributions to the development of modern art, literature and culture that would otherwise slip by unnoticed. In this way, this collection of essays acts as a historiographical corrective. This has a transnational bearing, integrating local, seemingly national, phenomena into a wider context, thereby challenging a model of cultural history predicated on national segmentation which detaches local developments from international ones. The expressionism of the Finnish November Group, for example, was long treated as a Finnish speciality to be distinguished from the expressionism found on the other side of the Baltic or in Russia; that is, it was seen as unrelated to the wider transnational expressionist (avant-garde) network, articulating only the particularities of Finnish soul and soil.

The extent and contours of the wider Nordic involvement in, and advocacy of, the classical avant-garde have really only become a firmly established research subject in the past decade through the concerted efforts of a Danish interdisciplinary research network devoted to the "Return and Actuality of the Avant-Gardes", facilitated by the Danish Humanities Research Council from 2001-03, and the Nordic Network of Avant-Garde Studies, sponsored by the Nordic Research Board, Nordforsk, from 2004-09, which focused attention on two fronts: the avant-garde as a historiographical category and the historical presence of the classical and neo-avant-garde in the Nordic countries (cf. Ørum/Ping Huang/Engberg 2005).

In addition to organising conferences, the Nordic Network of Avant-Garde Studies is producing a four-volume history of the twentieth century avant-garde in the Nordic countries. This book is the first volume of this series and focuses on the first quarter of the 
twentieth century. As the first extensive exploration of the historical avant-garde in the Nordic countries, this book is far from exhaustive and does not claim to cover all native avant-garde manifestations in this period, nor all Nordic contributions to the classical avant-garde elsewhere in Europe. The present volume is thus intended to generate, rather than end, further research in the field. Indeed, the information gathered and conclusions drawn here lead to questions that exceed the scope of the volume, but which demand to be addressed in order that a more precise picture of the role of the avant-garde in the Nordic countries can emerge, namely: What has been the wider cultural impact of the Nordic avant-garde? What role has it played in the shaping of cultural modernity in the Nordic countries? To what extent and in which ways has the avant-garde been received and recuperated within the wider cultural field and society as whole? Given the marginality of the classical avant-garde in Europe in general, and in the Nordic countries in particular, it may be supposed that this impact was certainly limited in the first decades of the twentieth century. And yet, there can be no doubt that the initial avantgarde anticipated, or rather, prepared the way for later developments within both the arts and the wider cultural field - as much in the Nordic countries as elsewhere.

\section{NOTES}

\footnotetext{
${ }^{0}$ This introduction is based on research funded by the Groningen Institute for the Study of Culture (ICOG) in the Faculty of Arts of the University of Groningen, the Netherlands Organisation for Scientific Research (NWO) and the Deutsches Literaturarchiv, Marbach am Neckar, as well as on discussions within the framework of the Danish interdisciplinary research network "The Return and actuality of the avant-gardes" and the Nordic Network of Avant-Garde Studies in the past decade. In particular, I would like to thank my fellow editors Dorthe Aagesen, Per Stounbjerg, Rikard Schönström for their critical comments and advice and especially Benedikt Hjartarson for supplying me with many valuable new details. For information on Niels Rydeng and his relation to various painters of the November group, I would like to thank the town archive of Helsingør, the local historian Torben Bill-Jessen as well as Peter Sandholt, curator of the museum Hammermøllen in Hellebæk.

${ }^{1}$ Cf.: Lothar Schreyer: Spielgang Skirnismól (MS, 1920), in: Deutsches Literaturarchiv, Marbach am Neckar, Handschriftenabteilung, NL Schreyer, Sturm-Archiv,
} 
Kasten A1, Inv.nr. 65.861.

${ }^{2}$ Cf. Letters from Kristiania by Herwarth Walden to his secretary Eva [Spector-] Weinwurzel in Berlin, dated 6 and 10 October 1923, in: Deutsches Literaturarchiv, Marbach am Neckar, Handschriftenabteilung, Inv.nr. 67.1957/19 and 67.1957/20.

${ }^{3}$ The fact may be incidental, but Hugo Ball's roman à clef on the foundation of the Cabaret Voltaire and Dada, Flametti oder Vom Dandysmus der Armen from 1918 appeared in Swedish translation as early as 1920 - in Helsinki/Helsingfors. Translations into other languages would follow more than half a century later.

${ }^{4}$ Although some Swedish and Danish authors and artists published programmatic texts in their own languages, e.g. Per Lagerkvist's Ordkonst och bildkonst (1913) and Gösta Adrian Nilsson's Den gudomliga geometrien (1922) in Swedish and Otto Gelsted's Ekspressionisme (1919) and Rud(olf) Broby (Johansen's) Kunst (1923) in Danish.

${ }^{5}$ Transtated by Kerry Graves. 


\section{WORKS CITED}

Aagesen, Dorthe (ed.). 2002. Avantgarde i dansk og europaisk kunst 1909-1919. Copenhagen.

Ahlstrand, Jan Torsten, et al. 2000. Svenskt Avantgarde och Der Sturm i Berlin. Schwedische Avantgarde und Der Sturm in Berlin. Osnabrück/Lund 2000.

Alin, Margareta, and Kjerström Sjölin, Eva (eds). 1997. Aspekter på Modernismen. Kulturen 1997. En Airsbok till medlemmarna av Kulturhistoriska Föreningen för Södra Sverige. Lund.

Alms, Barbara, and Steinmetz, Wiebeke (eds). 2000. Der Sturm im Berlin der zehner Jahre. Delmenhorst.

Amberg, Anna-Lisa. 2003. "Kotini on linnani" - kartano ylemmän porvariston omanakuvana. Esimerkkinä Geselliuksen, Lindgrenin ja Saarisen suunnittelema Suur-Merijoki vuodelta 1904. Helsinki.

Andersen, Troels, and Nyholm, Tove. 1995. Asger Jorn og 10.000 års nordisk folkekunst. Silkeborg.

Anonymous. 1897. Enquête sur l'influence des lettres scandinaves. In: La Revue Blanche 12 1897: 153-166.

—. 1924. Het netwerk. In: Het Overzicht 3 (20) 1924: 136.

—. 1973. Tjeckiskt avantgarde 1900-1939. Stockholm.

Arp, Hans. 1919. Aus: Die Wolkenpumpe. In: Flake, Otto, and Serner, Walter, and Tzara, Tristan (eds): Der Zeltweg Zürich 1919: 12-14.

-. 1920. die wolkenpumpe. Hannover.

Arp, Hans, and Lissitzky, El. 1925. Die Kunstismen. Les Ismes de l'art. The Isms of Art. Erlenbach/München/Leipzig 1925.

Asholt, Wolfgang, and Fähnders, Walter (eds.). 1995. Manifeste und Proklamationen der europäischen Avantgarde (1909-1938). Stuttgart.

—. 1997. 'Die ganze Welt ist eine Manifestation'. Die Avantgarde und ihre Manifeste (1909-1938). Darmstadt.

Askeland, Jan, et al. 1987. Konkret i Norden 1907-1960. Pohjoinen konkretismi 19071960. Norran konkretlist 1907-1960. Nordic concrete art 1907-1960. Helsinki.

Bak, Aase, and Ørskou, Gitte (eds). 2009. Emil Nolde og Danmark. Emil Nolde und Dänemark. Aalborg.

Ball, Hugo. 1918. Flametti oder Vom Dandysmus der Armen. Berlin.

-. 1920. Flametti eller De fattigas dandyism. Helsingfors.

Bauschinger, Sigrid. 2004. Else Lasker-Schüler. Biographie. Göttingen.

Beeren, Wim (ed.). 1992. The Great Utopia. Russian Avant-Garde 1915-1932. Amsterdam.

Benninghoff, Ludwig. 1924. Gepraegte Form. Zeugnisse unserer seelischen Schöpferkraft. Hamburg.

Benson, Timothy O. (ed.). 2002. Central European Avant-Gardes. Exchange and Transformation, 1910-1930. Cambridge, Mass./London.

van den Berg, Hubert. 1990. "Dichter en muiterkapitein". Het gedwongen oponthoud van Franz Jung in Nederland. In: Het Oog in 't Zeil 7 (5-6) 1990: 4148. 
- 1999. Avantgarde und Anarchismus. Dada in Zürich und Berlin. Heidelberg.

—. 2000. "Übernationalität" der Avantgarde - (Inter-)Nationalität der Forschung. Hinweis auf den internationalen Konstruktivismus in der europäischen Literatur und die Problematik ihrer literaturwissenschaftlichen Erfassung. In: Asholt, Wolfgang, and Fähnders, Walter (eds): Der Blick vom Wolken-kratzer. Avantgarde - Avantgardekritik - Avantgardeforschung. Amsterdam/Atlanta 2000: 255-288.

—. 2005a. "... wir müssen mit und durch Deutschland in unserer Kunst weiterkommen." Jacoba van Heemskerck und das geheimdienstliche "Nachrichtenbüro 'Der Sturm'”. In: Josting. Petra, and Fähnders, Walter (eds): "Laboratorium Vielseitigkeit”. Zur Literatur der Weimarer Republik. Festschrift für Helga Karrenbrock. Bielefeld 2005: 67-87.

—. 2005b. Kortlægning af det nyes gamle spor. Bidrag til en historisk topografi over det 20. århundredes avant-garde(r) i europæisk kultur. In: Ørum, Tania, and Ping Huang, Marianne, and Engberg, Charlotte (eds): En tradition af opbrud. Avantgardernes tradition og politik. Hellerup 2005: 19-43.

—. 2006a. "Mapping old traces of the new. For a historical topography of 20thcentury avant-garde(s) in the European cultural field(s)". In: Arcadia 41 (2) 2006: 331-351.

—. 2006b. Jón Stefánsson og Finnur Jónsson: Frá Íslandi til evrópsku framúrstefnunnar og aftur til baka. Framlag til kortlagningar á evrópsku framúrstefnunni á fyrri helmingi tuttugustu aldar. In: Ritið 6 (1) 2006: 51-77.

—. 2009. Der Sturm als Kunsthandlung und Nachrichtenbüro in der deutschen Propagandapolitik in den neutralen Nachbarländern während des Ersten Weltkriegs. In: Briens, Sylvain, and Mohnike, Thomas (eds): Capitales culturelles et Europe du Nord. Kulturhauptstädte Nordeuropas. Strasbourg 2009: 135152.

-. 2010. Lothar Schreyers Beiträge in Die Unvergessenen. Hinweis auf eine historische Verknüpfung von klassischer Avantgarde und konservativer Revolution', in: Żarska, Natalia, and Diesener, Gerald,. and Kunicki, Wojciech (eds): Ernst Jünger - eine Bilanz. Leipzig 2010: 178-199.

van den Berg, Hubert, and Fähnders, Walter (eds). 2009. Metzler Lexikon Avantgarde. Stuttgart/Weimar.

Berninger, Herman, and Cartier, Jean-Albert (eds). 1992. Jean Pougny. Catalogue de l'oeuvre. Tübingen, 2 vol.

Böhme, Frank. 2006. Hans Heinz Stuckenschmidt. Komponist und Musik-schriftsteller in Hamburg. In: In: Joppien, Rüdiger (ed.). Entfesselt. Expressionismus in Hamburg um 1920. Hamburg, 2006: 65-69.

Bønnelycke, Emil. 1918. Berlin. In: Klingen 1 (9-10) 1918: s.p.

Bourdieu, Pierre. 1992. Les règles de l'art. Genèse et structure du champ littéraire. Paris.

- 1993. The Field of Cultural Production. Essays on Art and Literature. Cambridge.

Bradbury, Malcolm, and McFarlane, James (eds). 1978. Modernism 1890-1930. Hassocks.

Brandes, Georg. 1883. Det moderne gjennembruds mand. Copenhagen. 
-. 1872. Hovedstrømninger i det 19de Aarhundredes Litteratur. Forelasninger holdte ved Kjøbenhavns Universitet i Efteraarshalvaaret 1871. Vol. I: Emigrantlitteraturen. Copenhagen.

—. 1901. Main Currents in Nineteenth Century Literature, Vol. 1: The Emigrant Literature,

Briens, Sylvain, and Mohnike, Thomas (eds). 2009. Capitales culturelles et Europe du Nord. Kulturhauptstädte Nordeuropas. Strasbourg.

Brühl, Georg. 1983. Herwarth Walden und "Der Sturm”. Leipzig.

Brusberg, Dieter. 1995. Wladimir Baranoff-Rossiné. Bilder und Blätter 1907 bis 1938. Berlin.

Bürger, Peter. 1974. Theorie der Avantgarde. Frankfurt/M.

—. 2005. Rebellion am Badesee. Die Künstlergruppe Die Brücke wird 100 und überall als Avantgarde gefeiert. War sie das wirklich? At:

http://www.zeit.de/2005/23/Die_Bruecke [page visited in September 2005].

Bužinska, Irēna. 2000. Voldemārs Matvejs (1877-1914). Visby.

Calinescu, Matei. 1977. Five Faces of Modernity. Modernism, Avant-Garde, Decadence, Kitsch, Postmodernism. Bloomington/Indianapolis.

Casanova, Pascale. 2004. The World Republic of Letters. Cambridge, Mass./London.

Cepl-Kaufmann, Gertrude, and Kauffeldt, Rolf. 1994. Berlin-Friedrichshagen. Literaturhauptstadt um die Jahrhundertwende. Der Friedrichshagener Dichterkreis. München.

Claustrat, Frank. 1994. Les artistes suédois à Paris 1908-1935: tradition, modernisme et création. Paris, 4 vol.

Cohen, David (ed.). 2001. Académie Matisse. Henri Matisse and his Nordic and American Pupils. New York.

Datta, Venita. 1999. Birth of a National Icon. The Literary Avant-Garde and the Origins of the Intellectual in France. Albany.

Deleuze, Gilles, and Guattari, Félix. 1976. Rhizome. Introduction. Paris.

—. 1980. Mille Plateaux. Capitalisme et schizophrénie. Paris.

Derouet, Christian, et al. (eds.). 1992. Léger och Norden. Stockholm.

Derry, T.K. 1979. A History of Scandinavia: Norway, Sweden, Denmark, Finland and Iceland. London.

van Doesburg, Theo. 1921a. Revue der Avant-garde [Frankrijk]. In: Het Getij 6/1 (1) $1921: 109-112$

—. 1921b. Revue der Avant-garde. Duitschland. In: Het Getij 6/1 (3) 1921: 193-200.

—. 1921c. Revue der Avant-garde. België. In: Het Getij 6/2 (1) 1921: 25-29.

-. 1921d. Revue der Avant-garde. Italië [I]. In: Het Getij 6/2 (6) 1921: 138-141.

—. 1921e. La littérature d'avant-garde en Hollande. In: Ça Ira 1 (12) 1921: 241-244.

—. 1922. Revue der Avant-garde. Italië [II]. In: Het Getij 7 (1) 1922: 13-15.

Echte, Bernhard (ed.). 1999. Emmy Ball-Hennings 1885-1948. „... ich bin so vielfach“. Texte, Bilder, Dokumente. Frankfurt/M./Basel.

Essig, Hermann. 1997. Der Taifun. Roman. Bonn.

Ettrup, Lise, et al. (eds). 1993. Det modernes gjennombrudd i Norden. Oslo.

Eysteinsson, Ástráður. 1990. The Concept of Modernism. Ithaca/London. 
-. 2008. Does Modernism Work as a European Concept? In: Jansson, Mats, et al. (eds): Comparative Approaches to Nordic and European Modernisms. Helsinki 2008: 17-32.

Eysteinsson, Ástráður, and Liska, Vivian (eds). 2007. Modernism. Amsterdam/ Philadelphia, 2 vol.

Fähnders, Walter. 2000. Projekt Avantgarde und avantgardistischer Manifestantismus. In: Asholt, Wolfgang, and Fähnders, Walter (eds): Der Blick vom Wolkenkratzer. Avantgarde - Avantgardekritik - Avantgardeforschung. Amster$\mathrm{dam} /$ Atlanta 2000: 69-95.

Fosli, Halvor.1997. Kristianiabohemen. Byen, miljøet, menneska. Oslo.

Frascina, Francis (ed.). 1993. Modernity and Modernism: French painting in the Nineteenth Century. New Haven/London.

Genzmer, Felix. 1913. Das alte Spruchgedicht. Aus der Edda. In: Die Aktion 3 (50) 1913: 1162-1163.

Gleizes, Albert, and Metzinger, Jean. 1912.Du „cubisme“. Paris.

Głuchowska, Lidia. 2009. Totenmesse, Lebensfries und Die Hölle. Przybyszewski, Munch, Vigeland und die protoexpressionistische Kunsttheorie. In: BriensSylvain, and Mohnike, Thomas (eds): Capitales culturelles et Europe du Nord. Kulturhauptstädte Nordeuropas. Strasbourg 2009: 79-116.

Goll, Iwan. 1921. Paris brennt. Zagreb.

Gustafsson, Harald. 2007. Nordens historia. En Europeisk region under 1200 år. Lund.

Habermas, Jürgen. 1990. Die Moderne - ein unvollendetes Projekt. Aufsätze 19771990. Leipzig.

Hammer, Martin, and Lodder, Christina. 2000. Constructing modernity. The Art and Carreer of Naum Gabo. New Haven, CT.

Hennings, Emmy. 1916. Gesang zur Dämmerung. In: Ball, Hugo (ed.): Cabaret Voltaire. Eine Sammlung künstlerischer und literarischer Beiträge. Zürich 1916: 12 .

Henningsen, Bernd, et al. (eds). 1997. Wahlverwandtschaft. Skandinavien und Deutschland 1800 bis 1914. Berlin/Stockholm/Oslo.

Henrikson, Thomas. 1971. Romantik och marxism. Estetik och politik hos Otto Ville Kuusinen och Elmer Diktonius till och med 1921. Helsinki.

Hepp, Corona. 1987. Avantgarde. Moderne Kunst, Kulturkritik und Reformbewegungen nach der Jahrhundertwende. München.

Heusler, Andreas (ed.). 1920. Edda. Jena, 2 vol.

Hjartarson, Benedikt. 1997. Mótun framtiðar: um verkefni evrópsku framúrstefnunnar. Reykjavík.

Hjartarson, Benedikt, Eysteinsson, Ástráđur, and Árnason, Vilhjálmur (eds). 2001. Evrópska framúrstefnan. Yfirlýsingar. Reykjavík.

Hultén, Pontus (ed.). 1978. Paris - Berlin1900 - 1933. Rapports et contrastes France - Allemagne 1900 - 1933. Paris.

Ilmonen, Anneli, et al. 1999. Tyko Sallinen. Helsinki

Ilvas, Juha (ed.). 1996. Akseli Gallén-Kallela. Helsinki

Jelsbak, Torben. 2006. Ekspressionisme. Modernismens formelle gennembrud i Dansk malerkunst og poesi. Hellerup. 
Jæger, Hans. 1885. Fra Kristiania-Bohêmen. Roman. Kristiania.

Källström, Staffan. 2000. Framtidens Katedral. Medeltidsdröm och utopisk modernism. Stockholm.

Karlsson, Gunnar. 2005. Iceland's 1100 years. The History of a Marginal Society. London.

Kassák, Lajos, and Moholy-Nagy, László. 1922. Buch neuer Künstler. Wien.

Kent, Neil. 1987. The Triumph of Light and Nature. Nordic Art 1740-1940. London.

- 1990. Light and nature in late 19th century Nordic art and literature. Uppsala.

-. 2000. The Soul of the North. A Social, Architectural and Cultural History of the Nordic Countries, 1700-1940. London.

Kesting, Edmund (ed.). 1925. Schule Der Weg. Berlin/Dresden.

Kiblickij, Iozef (ed.). 2007. Vladimir Baranov-Rossiné. The Artist of Russian AvantGarde. Bad Breisig.

Kielgast, Anne, et al. (eds). 2006. Moderne kvinder. Kvindelige malere i Norden 19101930. København, Göteborg, Trondheim.

Kleine, Gisela. 1994. Gabriele Münter und Wassily Kandinsky. Biographie eines Paares. Frankfurt/M.

Klinge, Matti. 1995. The Baltic World. Helsinki.

Koja, Stephan (ed.). 2005. Nordlicht. Finnlands Aufbruch zur Moderne 1890-1920. Wien.

Komonen, Markku. 1986. Saarinen Suomessa. Saarinen in Finland. Gesellius, Lindgren, Saarinen 1896-1907, Saarinen 1907-1923. Helsinki.

Korvenmaa, Pekka. 1991. Innovation versus tradition. The architect Lars Sonck. Works and projects 1900-1910. Helsinki.

Kropotkin, Petr. 1970. An Appeal to the Young. In: Baldwin, Roger N. (ed.): Kropotkin's Revolutionary Pamphlets. New York.

Kujundžić, Dragan, and Jovanov, Jasna. 1998. Yougo-Dada. In: Janacek, Gerald (ed.): The Eastern Dada Orbit: Russia, Georgia, Ukraine, Central Europe and Japan. New York/London 1998: 41-62.

Kuusi, Matti, and Anttonen, Pertti. 1999. Kalevala-lipas. Helsinki.

Kvam, Kela. 1974-78. Europaisk avantgarde teater 1896-1930. Tekster, kommentarer. Odense, 4 vol.

Lahoda, Vojtĕch (ed.). 2006. Local Strategies, international ambitions. Modern art and Central Europe 1918-1968. Praha.

Lalander, Folke (ed.). 1979. Svenskt avantgarde: kubism, futurism, purism, nonfiguration. Från 10-talets genombrott till tiden efter andra världskriget. Norrköping.

Lasker-Schüler, Else. 2003. Mein Herz. Ein Liebes-Roman. Frankfurt/M.

Lengefeld, Cecilia. 2001. Avantgarde im Abseits. Künstlerkolonien in Dänemark, Norwegen, Schweden und Finnland. In: Pese, Claus (ed.): Künstlerkolonien in Europa. Im Zeichen der Ebene und des Himmels. Nürnberg 2001: 139-151.

Levanto, Marjatta. 1987. Ateneum Guide. From Isak Wacklin to Wäinö Aaltonen. Helsinki.

Lippard, Lucy R. 1983. Overlay. Contemporary Art and the Art of Prehistory. New York. 
Loesch, Lise. 1980. Tamme fugle langes - vilde fugle flyver. Avantgardelyrik i Danmark, Finland og Sverige i mellemkrigstiden. Copenhagen.

Marcks, Gerhard. 1923. Das Wieland-Lied der älteren Edda. Weimar.

Mark, Jan. 1999. Nell i stormen. En ung Svenska mitt i den moderna konstens genombrott. Landskrona.

Mas, Josiane (ed.). 2008. Arts en mouvement. Les Ballets Suédois de Rolf de Maré, Paris 1920-1925. Montpellier.

Meyer, Raimund. 1985. "Dada ist groß, Dada ist schön”. Zur Geschichte von "Dada Zürich". In: Bolliger, Hans, and Magnaguagno, Guido, and MeyerRaimund (eds): Dada in Zürich. Zürich 1985: 9-95.

Moberg, Ulf Thomas (ed.). 1995. Nordisk konst i 1920-talets avantgarde. Uppbrott och gränsöverskridande. Stockholm.

Mohler, Armin. 2005. Die konservative Revolution in Deutschland 1918-1932. Ein Handbuch. Graz.

Møller Kristensen, Sven. 1988. Avantgarden og haren. Literatursociologiske essays. København.

Mørch, Hilde. 1993. Tre norske avantgardekunstnere i 1920-årene: Ragnhild Keyser (18891943), Ragnhild Kaarbo (1888-1949), Charlotte Wankel (1888-1969). Oslo.

Nash, Steven A., and Merkert, Jörn (eds). 1985. Naum Gabo. Sixty years of Constructivism. München.

Negri, Antonio, and Hardt, Michael. 2000. Empire. Cambridge, Mass.

-. 2004. Multitude. War and democracy in the age of empire. New York.

Nerhus, Hans. 1982. John Andreas Savio. Same og kunstner. En monografi. Oslo.

Niehof, Reiner, and Bertoncini, Valeska (eds). 2005. Über Hans-Jürgen von der Wense. Frankfurt/M.

Nurminen, Kirsi-Marja. 1996. Avant Garde-etujoukko Helsingin Ylioppilasteatterin toiminta vuosina 1972-1981. Jyväskylä.

Ojanperä, Riitta (ed.). 2001. Surface and depth. Early Modernism in Finland 18901920. Helsinki.

-. 2009. The Kalevala in Images. Helsinki.

O'Konor, Luise. 1971. Viking Eggeling 1880-1925. Artist and Film-maker. Life and Work. Stockholm.

—. 2006. Viking Eggeling 1880-1925. Modernist och filmpionjär. Hans liv och verk. Stockholm.

Ørum, Tania, and Ping Huang, Marianne, and Engberg, Charlotte (eds). 2005. En tradition af opbrud. Avantgardernes tradition og politik. Hellerup.

Osorio T., Nelson (ed.). 1988. Manifiestos, proclamas y polémicas de la vanguardia literaria hispanoamericana. Caracas.

Pallasmaa, Juhani. 2006. Hvitträsk. Koti taideteoksena. The Home as a Work of Art. Helsinki.

Perry, Gill. 1994. Primitivism and the 'Modern. In: Harrison, Charles, Frascina Francis, Perry, Gill (eds): Primitivism, Cubism, Abstraction. The Early Twentieth Century. New Haven/London 1994: 3-85.

Pevsner, Aleksei. 1964. A biographical sketch of my brothers Naum Gabo and Antoine Pevsner. Amsterdam. 
Piotrowski, Piotr. 2009. Toward a Horizontal History of the European AvantGarde. In: Bru, Sascha, et al. (eds.): Europa! Europa? The Avant-Garde, Modernism and the Fate of a Continent. Berlin 2009: 49-58.

Pirsich, Volker. 1985. Der Sturm. Eine Monographie. Hertzberg.

—. 2000. Ausstellungen der Galerie DER STURM 1912-1919. In: Alms, Barbara, and Steinmetz, Wiebeke (eds): Der Sturm im Berlin der zehner Jahre. Delmenhorst 2000: 257-270.

Poggioli, Renato. 1968. The Theory of the Avant-garde. Cambridge, Mass.

Pust, Dieter. 2000/2001. Emmy Hennings in Flensburg 1885-1905. Eine Jugend im Kaiserreich. In: Hugo-Ball-Almanach 24 2000: 113-128 and 25 2001: 99-223.

Rautiainen, Tarja. 1996. Avantgarde, pop ja postmoderni suomalaisessa 1960-luvun musiikkiradikalismissa. Tampere.

Reetz, Bärbel. 2001. Emmy Hennings. Leben im Vielleicht. Eine Biographie. Frankfurt/M.

Reidemeister, L., ed., Der Sturm. Herwarth Walden und die europäische Avantgarde, Berlin 1912-1932. Berlin 1962.

Rowinski, Stanislaw. 2006. Lavinia Schulz und ihre künstlerischen Inspirations-quellen. In: Joppien,

Rüdiger (ed.). Entfesselt. Expressionismus in Hamburg um 1920. Hamburg, 2006: 51-63.

Saehrendt, Christian. 2005. "Die Brücke zwischen Staatskunst und Verfemung. Expressionistische Kunst als Politikum in der weimarer Republik, im "Dritten Reich" und im Kalten Krieg. Wiesbaden.

Salmela-Hasán, Katriina, et al. (eds). 1994. Picasso ja kubismi Suomessa. Picasso and Cubism in Finland. Punkaharju.

Sandberg, Lotte. 1987. Den italienske trans-avantgarden. En analyse av det inter-nasjonale gjennombruddet. Bergen.

Sanouillet, Michel. 1993. Dada à Paris. Paris.

Sarajas-Korte, Salme. 1968. Kubismi-Futurismi. Suomi ja kansainväliset taidesuunnat. Helsinki.

—. 1969. Kubismi - radikalismia vai klassisma. Kubismin käsityksestä Suomessa 1910-luvulla. In: Ateneumin taidemuseo. Museojulkaisu 14 1969: 2-16, 33-42, 45-49.

—. 1970. Kandinsky ja Suomi I (1906-1914). In: Ateneumin taidemuseo. Museojulkaisu 15 1970: 2-14, 32-38, 42-45.

—. 1971. Kandinsky ja Suomi II (1916). Venäläinen näyttely ja Kandinskyn yktyisnäyttely 1916. In: Ateneumin taidemuseo. Museojulkaisu 16 1971: 2-6, 34-36, 44-46.

Sauvageot, Aurélien. 1968. Histoire de la Finlande. Paris, 2 vol.

Schreyer, Lothar. 1926. Skirnismol. In: Blätter für Laien- und Jugendspiele (3) 1926: 11-14.

—. 1931. Die bildende Kunst der Deutschen. Geschichte und Betrachtung. Hamburg.

Schultz, Joachim. 1995. Wild, irre und rein. Wörterbuch zum Primitivismus der literarischen Avantgarden in Deutschland und Frankreich zwischen 1900 und 1940. Gießen. 
Seiwert, Harry. 1993. Marcel Janco. Dadaist-Zeitgenosse - wohltemperierter morgenländischer Konstruktivist. Franfurt/M.

Siivonen, Timo. 1992. Avantgarde ja postmodernismi. Itsekritiikki ja radikalisoituminen modernissa taideinstituutiossa. Jyväskylä.

Sinisalo, Soili. 1993. Suomalaisita, venäläisistä, avantgardesta. In: Sariola, Helmiriitta, and Jaakkola, Leena (eds): Avantgarde 1900 - 1930. Tšudnovskin kokoelma Pietarista. Helsinki 1993: 58-75.

-. 1998. The St Petersburg - Helsinki axis one hundred years ago. In: PertrovaYegenia (ed.): Mir iskusstva. On the Centenary of the Exhibition of Russian and Finnish Artists 1898. Bad Breisig 1998: 6-11.

Sørensen, Gunnar. 2010. The visual arts in Norway today. At: http://www.reisenett.no/norway/facts/culture_science/visual_arts.html [Page visited May 2010]

Sørensen, Peer E.. 2004. Georg Brandes, Herman Bang, Johannes Jørgensen og Goethe. In: Harsløf, Olav (ed.): Georg Brandes og Europa. København 2004: 177-192.

Stokvis, Willemijn. 1980. Cobra. Geschiedenis, voorspel en betekkenis van een beweging in de kunst van na de tweede wereldoorlog. Amsterdam.

Subotić, Irina. 1990. Avant-Garde Tendencies in Yugoslavia. In: Art Journal 49 (1)1990: 21-27.

Terman Frederiksen, Finn. 1987-1988. Franciska Clausen. Randers. 2 vol.

de Vries, Jan. 2001. Impresario's van de avant-garde. In: Kunstschrift 45 (2) 2001: 18-31.

Walden, Herwarth (ed.). 1914. Der Blaue Reiter. Utställning i Salon Strindberg. Berlin.

—. 1917. Einblick in Kunst. Expressionismus, Futurismus, Kubismus. Berlin.

-. 1918a. Expressionismus - die Kunstwende. Berlin.

-. 1918b. Der Sturm. International Kunst. Ekspressionister og Kubister. Malerier og Skulpturer. Copenhagen.

von der Wense, Hans-Jürgen. 1999. Geschichte einer Jugend. Tagebücher und Briefe. München.

Werenskiold, Marit. 1972. De Norske Matisse-elevene, laretid og gjennombrudd 1908-1914. Jean Heiberg, Henrik Sørensen, Per Krohg, Axel Revold, Per Deberitz, Severin Grande, Kristoffer Holst, Bernhard Greve, Einar Sandberg, Alf Lundeby, Ludvig Karsten, Rudolph Thygesen. Oslo.

—. 1974. Die „Brücke“ in Skandinavien. Zwei Ausstellungen in Kopenhagen und Christiania 1908. In: Brücke-Archiv 7 1974: 3-21.

—. 1980. Herwarth Walden. Ekspresjonismens apostel i Skandinavia 1912-1923. In: Kunst og kultur 63 1980: 143-158.

-. 1984. The Concept of Expressionism. Origin and metamorphoses. Oslo.

—. 1997. Die Avantgarde in Dresden, München und Berlin: Die Brücke, Der Blaue Reiter, Der Sturm. In: Henningsen, Bernd, et al. (eds): Wahlver-wandtschaft. Skandinavien und Deutschland 1800 bis 1914. Berlin/Stockholm/Oslo 1997: 370-372

Westheider, Ortrud. 2000. Die Tournee der erste Ausstellung des Blauen Reiters. 
Eine Rekonstruktion in Korrespondentenberichten. In: Hopfengart, Christine (ed.): Der Blaue Reiter. Bremen/Köln 2000: 49-82.

Wietek, Gerhard. 1985. Skandinavien und der deutsche Expressionismus. Schleswig. Winskell, Kate. 1995. The Art of Propaganda. Herwarth Walden and "Der Sturm" 1914-1919. In: Art History 18 1995: 315-344.

Wood, Paul (ed.). 1999. The Challenge of the Avant-Garde. New Haven, CT.

Würtz Frandsen, Jan. 1993. Max Ernst og tredivernes danske avant-garde. Copenhagen.

Ylikangas, Heikki. 1993. Tie Tampereelle: dokumentoitu kuvaus Tampereen antautumiseen johtaneista sotatapahtumista Suomen sisällissodassa 1918. Porvoo. 